\title{
"Whoa, Edgar": \\ The Des Moines Register and Tribune, \\ Cowles Publications, and \\ J. Edgar Hoover's FBI
}

\author{
MATTHEW CECIL
}

ON FEBRUARY 3, 1951, Louis B. Nichols, the powerful head of the public relations-oriented Crime Records Division of the Federal Bureau of Investigation (FBI), sent a memorandum to the bureau's second-highest-ranking official, Associate Director Clyde Tolson. In his memorandum, Nichols noted that he had met a young Cowles Publications reporter, Clark Mollenhoff. Nichols added that he came away impressed. He noted that in 1945 the Des Moines Special Agent in Charge had reported that Mollenhoff "was awkward, has a colorless personality, and does not appear to be a fluent talker." The agent thought Mollenhoff would not develop satisfactorily. "Of course six years can make a lot of difference but I got entirely a different impression of Mollenhoff. He, frankly, looked exceedingly good to me."1

The FBI was not interested in Mollenhoff's development as a watchdog journalist. Instead, given the FBI's long-term focus on public relations, it was interested in whether or not it could count on Mollenhoff to withhold criticism of the FBI, to amplify the FBI's successes, and, in certain circumstances, to come to the

1. Louis B. Nichols, Memorandum to Clyde Tolson, 2/3/1951, FBI file 94-8137-94.

The research for this article was supported by a grant from the State Historical Society of Iowa.

THE ANNALS OF IOWA 71 (Spring 2012). (C) The State Historical Society of Iowa, 2012. 
bureau's defense against critics. For example, just the day before Nichols made his assessment of Mollenhoff, he had written to Tolson regarding public statements by the governors of Iowa and Nebraska, who had been criticizing what they saw as the FBI's overzealous efforts to circumvent local police jurisdiction. "It seems to me that we should endeavor within the next two days to get up a good story of the Bureau's coverage and jurisdiction pitched from the local angles of Nebraska and Iowa," Nichols wrote, noting that the FBI had friends in newsrooms in Lincoln and Omaha who would surely help. In a handwritten note on the memo, FBI Director J. Edgar Hoover agreed: "I indicated some weeks ago a need for just such a story through our whole country." 2 Reporters like Mollenhoff, who represented newspapers in Des Moines and Minneapolis for Cowles Publications, were valuable contacts for FBI public relations officials.

Throughout the Hoover era, particularly from 1933 to 1972, the FBI monitored reporters, editors, publishers, and publications and evaluated them based on their willingness and ability to be helpful in amplifying the FBI's preferred public relations messages. ${ }^{3}$ In 1959 the bureau compiled a report, "Molders of Public Opinion," stating the agency's reasons for monitoring the press: "Looking at the following representative segment of those molding public opinion today, we can raise the question as to whether or not many have made themselves worthy of American ideals so that they may be entrusted with carrying forward human progress and dignity." 4

The "Molders" memorandum focused primarily on the alleged communist affiliations of high-profile national journalists like I. F. Stone, Walter Lippmann, Drew Pearson, and James A. Wechsler, but the voluminous FBI files on John and Gardner (Mike) Cowles, the Des Moines Register and Tribune, and Clark Mollenhoff and several other key staffers demonstrate that the

2. Louis B. Nichols Memorandum to Clyde Tolson, 2/2/1951, FBI file, unserialized. At times, the FBI failed to include a specific serial number on a document. Files are, however, generally organized in chronological order. Unserialized documents may be located within a given file using the date.

3. Using the Freedom of Information Act, I have collected more than 90,000 pages of FBI files on prominent journalists and publications.

4. William C. Sullivan, "Molders of Public Opinion," Memorandum to Alan H. Belmont, 3/18/1959, FBI file 100-40167-7, iii. 
bureau's interest in activities of the press extended to regional and local publications as well national ones.

The copious detail in the files reveals the lengths to which the FBI would go to build and maintain relationships with media representatives. Incidents when relationships faltered demonstrate ongoing evaluations by FBI officials who categorized journalists and publications as friend or foe. And the tenor of correspondence and contacts between the FBI and staff at the Register and Tribune and Cowles Publications offers a glimpse into the ways each side curried favor and sought access to the other. ${ }^{5}$ A review of these files also provides insight into how Hoover and the FBI viewed legendary journalists with Iowa connections-Mike and John Cowles, Clark Mollenhoff, William Wesley Waymack, Richard Lawson Wilson, and others.

ACTING against the wishes of Congress, Attorney General Charles J. Bonaparte created an investigative bureau within the Justice Department in 1908. Earlier that year, Congress had rejected an effort to create an investigative agency in the Justice Department, citing fears of centralized police power. ${ }^{6}$ That controversy created an ongoing crisis of legitimacy for the FBI and its precursor agencies, setting it up as a target for critics, particularly during periods when the bureau's jurisdiction and authority were expanded. Creating an image of restraint and utility to counter critics who questioned the legitimacy of FBI jurisdiction and tactics was a key motivator underlying the

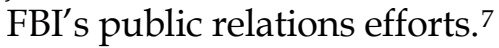

5. In 1903 Gardner Cowles purchased a controlling interest in the Des Moines Register. In the 1920s Cowles consolidated all of the major newspapers in Des Moines and formed the Register and Tribune Company, publishing the Register in the morning and the Tribune in the afternoon. In the 1930s, as his sons took over the company, they expanded to Minneapolis, eventually gaining control of all of the major papers in that city, then launching Look magazine and several other publications all under the auspices of Cowles Publications. See William B. Friedricks, Covering Iowa: The History of the Des Moines Register and Tribune Company (Ames, 2000)

6. Athan Theoharis et al., eds., The FBI: A Comprehensive Reference Guide (New York, 2000), 141-42; Athan Theoharis and John Stuart Cox, The Boss: J. Edgar Hoover and the Great American Inquisition (Philadelphia, 1988), 43, 84, 88, 99.

7. Theoharis et al., eds., The FBI, 102-3, 141-42. 


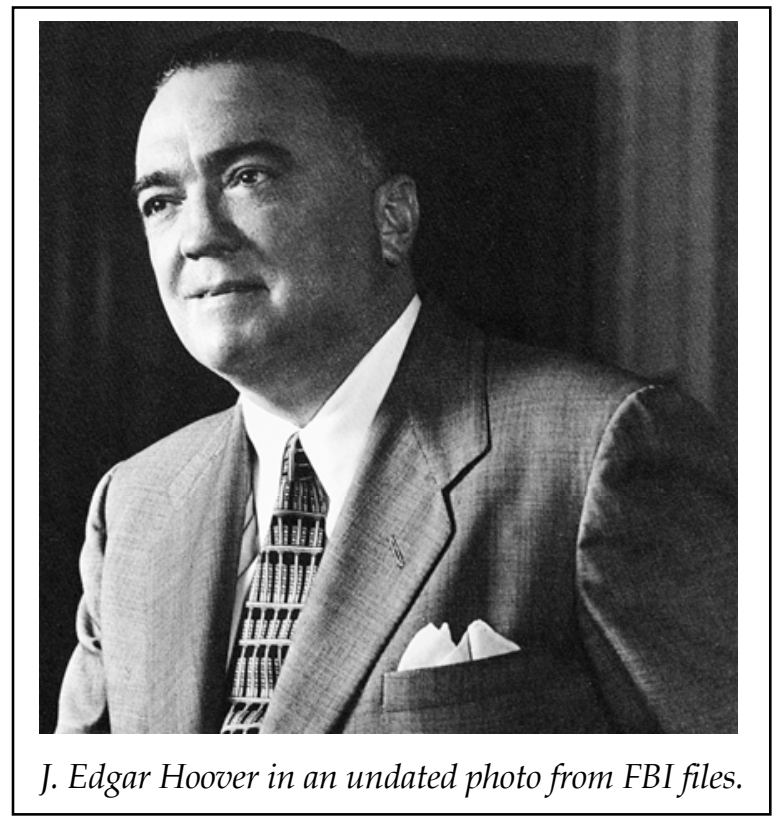

J. Edgar Hoover had previously served as head of the General Intelligence Division of the Justice Department and was a key figure in the controversial 1920 Red Scare Palmer Raids that rounded up suspected anarchists and communists. He became director of the Bureau of Investigation four years later. From 1924 to 1934, Hoover's bureau operated quietly, with much of the director's energy expended in reorganizing and professionalizing the organization. Specifically, Hoover spent those early years tuning the agency's bureaucratic structure and steering clear of the corruption temptations of prohibition enforcement. As late as 1934, when Hoover had been director of what was then the Division of Investigation (renamed the FBI in 1935) for ten years, the agency's work remained little known outside of Washington. Six years later, however, Hoover and his special agents were cultural icons, lionized in the news and entertainment media. ${ }^{8}$

8. Ibid., 362-64; Eugene Lewis, Public Entrepreneurship: Toward a Theory of Bureaucratic Political Power: The Organizational Lives of Hyman Rickover, J. Edgar Hoover, and Robert Moses (Bloomington, IN, 1980), 94; Richard Gid Powers, Secrecy and Power: The Life of J. Edgar Hoover (New York, 1987), 227. 
In those few years, Hoover's FBI moved from the fringes of the public mind to the center of politics and popular culture in America. President Franklin Delano Roosevelt's New Deal had gathered increased power within the federal government, including an emphasis on federal law enforcement and public relations. After dabbling in media relations in the early 1930s, Hoover created the Crime Records Division in 1935 and named Louis B. Nichols to head the division. Crime Records handled public affairs for the bureau throughout the remaining three decades of Hoover's tenure, and Nichols came to be considered by some to be the second most influential person in the history of the FBI. By 1936, the FBI had grown from fewer than 100 agents in 1930 to nearly 900 agents stationed in the Seat of Government, as FBI headquarters in Washington was called, and in 52 field offices nationwide. ${ }^{9}$

The once unknown Hoover and his FBI had become "reassuring symbol[s] of security and stability for most Americans." 10 For decades, reports of FBI exploits captured the public imagination as the agency grew in size, in jurisdiction, and as a source of public interest. FBI public relations efforts, beginning with the war on crime in the 1930s and continuing with the war on communism in the 1940s, 1950s, and 1960s, included an ongoing series of organized communication campaigns aimed at solidifying the bureau's position in society, establishing Hoover as America's top cop, and alleviating public fears of the bureau becoming an American secret police. ${ }^{11}$

Relationships with key reporters, editors, and publishers in Washington and across the country were key to Hoover's efforts to maintain his central position in American culture and government. ${ }^{12}$ In many cases, those reporters, editors, and publishers

9. Kenneth O'Reilly, "A New Deal for the FBI: The Roosevelt Administration, Crime Control, and National Security," Journal of American History 82 (1982), 642; Theoharis et al., eds., The FBI, 176, 346; Theoharis and Cox, The Boss, 157.

10. Powers, Secrecy and Power, 227.

11. Theoharis and Cox, The Boss, 43, 84, 88, 99.

12. See, for example, Matthew Cecil, “'Press Every Angle': FBI Public Relations and the 'Smear Campaign' of 1958," American Journalism 19 (2002), 39-58; and Matthew Cecil, "Friends of the Bureau: Personal Correspondence and the Cultivation of Journalist-adjuncts by J. Edgar Hoover's FBI," Journalism and Mass Communication Quarterly 88 (2011), 267-84. 
provided Hoover with a megaphone for his message and a willing team of defenders against criticisms of the FBI. In other cases, the relationships were merely a function of ongoing media relations efforts to promote the bureau's preferred image of itself through the pages of local and regional newspapers.

THERE ARE MYRIAD DEFINITIONS of public relations, but most scholars agree that the practice is distinguished from simple publicity by its focus on gaining insight into the nature of the audience. The term public relations was coined in 1920, when Edward Bernays outlined the practice in his book Crystallizing Public Opinion. Bernays later termed public relations work as the "engineering of consent" in which expert communicators research their audiences, gain an insight about what motivates a person to act, and craft persuasive messages for those narrowly defined groups of people. This strategic intent, the effort to engineer consent described by Bernays, separates the practice of public relations from earlier, non-strategic communication techniques like press agentry or publicity. ${ }^{13}$

Subsequent scholars have expanded the definition to include cultural aspects, focusing more clearly on the individuals who make up the audience. ${ }^{14}$ For the purposes of this study, public relations is defined as public communication seeking to build and maintain communities of meaning with those who share the organization's preferred image of itself. The relationships established through public relations techniques may be seen as a source of cultural capital for the organization, each relationship holding the potential for action on behalf of the communicator. Voters may vote. Supporters may come to an organization's de-

13. Edward Bernays, Crystallizing Public Opinion (New York, 1923), 166-67; Edward Bernays, "The Engineering of Consent," The Annals of the American Academy of Political and Social Science 250 (1947), 113.

14. This study relies on a composite definition arrived at after reviewing popular public relations textbooks and scholarly papers. I assume that public relations, as defined by the founder of the field, Edward Bernays, must include the gathering of insight into the audience, whether that is produced via formal or informal means. For an exploration of public relations definitions, see Dean Kruckeberg and Kenneth Starck, Public Relations and Community: A Reconstructed Theory (New York, 1988), 16. 
fense in a crisis. Common understandings create an atmosphere more conducive to change that is in the organization's interest. 15

The FBI was among the first government agencies in the United States to practice public relations on a broad scale and with a long-term vision. Beginning in 1934, the FBI developed a cohesive message that characterized its public relations messages for the ensuing 38 years of Hoover's tenure. That public relations template was designed to counter challenges to the agency's legitimacy borne in concerns about centralized federal law enforcement authority. Some early critics of the FBI worried about the creation of an American "Gestapo." Thus, the FBI's public relations messages emphasized neutral, scientific law enforcement, touted the organization's restraint, and promoted Hoover as America's top cop. ${ }^{16}$

But it was the information-gathering element of FBI public relations that was particularly groundbreaking. In the mid-1930s, the FBI formalized the public relations duties of the Special Agents in Charge (SACs), who supervised the more than 50 local offices of the FBI. Bureau manuals required each SAC to begin each day by reviewing local newspapers, clipping articles of interest to the FBI, visiting with key opinion shapers in the community, and forwarding all of that intelligence to Washington. SACs became the collectors of insight into the audiences for the FBI's message. Finally, the Crime Records Division compiled that information and communicated it to the FBI's top leadership. The bureau's Executive Conference, composed of the top handful of division leaders and assistant directors and chaired by Hoover's closest confidante, Associate Director Clyde Tol-

15. Public relations historians have disagreed about whether the practice existed prior to Bernays's twentieth-century epiphany or if Bernays simply defined a longstanding practice. In 2010 Margot Opdycke Lamme and Karen Miller Russell reviewed the scholarship and suggested that the strategic intent of an organization may be discerned from the scope and nature of tactics employed. In other words, by reviewing what kinds of public relations campaigns an organization engaged in, one can determine whether that organization was practicing strategic communication. Margot Opdycke Lamme and Karen Miller Russell, "Removing the Spin: Toward a New Theory of Public Relations History," Journalism and Communication Monographs 11 (2010), 354.

16. Stuart Ewen, PR! A Social History of Spin (New York, 1996), 365; Powers, Secrecy and Power, 94-98, 108-12. 
son, was responsible for identifying key challenges and making recommendations for public relations and other policies. ${ }^{17}$

FBI public relations policies were refined in 1936. Under the new rules, all news stories issued from the bureau came out over Hoover's signature. No one but Hoover could publicly accept credit for any FBI successes. SACs were prohibited from providing information about bureau activities to anyone outside the FBI, including news reporters, without receiving prior permission from Washington. Only Hoover was empowered to speak on policy or to respond to inquiries about ongoing investigations. All speeches delivered by special agents had to be cleared with Washington. SACs were even prohibited from recommending any books not included on the FBI's official bibliography. ${ }^{18}$

By the mid-1930s, the FBI was a bureau built for public relations. It had a ready-made public relations template emphasizing science, restraint, and Hoover. It boasted an in-house public relations division, more than 50 SACs gathering insight in the field, and a policy-making group of top managers in Washington. Most FBI monitoring and evaluation of national and regional reporters, editors, and publishers can be traced in FBI files to the mid-1930s. That sophisticated system of information gathering and evaluation led individuals and their publications to be categorized as friend or foe. The national journalists who merited mention in the "Molders of Public Opinion" report were clearly labeled as enemies of the FBI because their backgrounds or their work included what the bureau considered to be subversive elements.

More commonly, though, the FBI reached no definitive and final conclusion about individual reporters or their publications. Typically, FBI officials revisited their judgments periodically. Hoover and the Crime Records Division had long memories for what they perceived as criticism of the FBI, but absent a sustained campaign of "subversive" content, most publications and individuals had an up-and-down relationship with the bureau. The staff of the Des Moines Register and Tribune and Cowles Publications exemplify that sort of relationship with the FBI.

17. Sullivan, "Molders of Public Opinion," 15-16; Theoharis et al., eds., The FBI, 214.

18. Manual, Bureau of Investigation, Department of Justice, ca. 1927, 1936, chap. 2, sections 22, 23, 25, pp. 30-31. 
HOOVER'S COLLABORATIONS with the Des Moines Register and Tribune began in 1934 when what was then known as the Division of Investigation was just beginning to expand its public relations efforts. That year, the division's high-profile pursuit of outlaw John Dillinger played out in the press. With the surge of interest in Dillinger and other midwestern outlaws, the division began evaluating individual reporters and publications when a reporter or editor contacted the agency seeking access to law enforcement information. Those evaluations-determining whether or not reporters and their publications were friendly - were ongoing; conclusions that were drawn in the moment lived on, sometimes for decades, in subsequent bureau memoranda evaluating media organizations and individual journalists.

The first substantive collaboration between the Division of Investigation and the Des Moines Tribune occurred in 1934 when reporter Richard L. Wilson contacted Hoover's closest adviser, Clyde Tolson, who had grown up in Cedar Rapids, Iowa, to inquire about writing a series of stories on the spate of kidnappings then plaguing the middle third of the United States. Wilson was given a series of case summaries and photographs to prepare his stories. ${ }^{19}$ When Wilson's articles were published in February and March 1934, they were reviewed in Washington by Inspector W. H. Drane Lester, who found them well written and interesting but was concerned by the repeated use of the term "Black Chamber" to refer to the Division of Investigation. The phrase, a reference to the brutal tactics of the Spanish Inquisition, directly conflicted with the restrained image Hoover and his public relations team preferred to project. "It will, I fear, give the reader the idea that third degree methods are used by the Division of Investigation," Lester wrote. Hoover agreed, scrawling a note at the bottom of the memorandum: "I agree that we should discourage the use of the phrase 'Black Chamber.' " 20

Ten years later, the bureau might have blackballed Wilson for employing creative license that undermined the FBI's public relations message. But in those early days of Division of Investigation public relations, prior to the arrival of Louis B. Nichols

19. Clyde Tolson, memorandum for J. Edgar Hoover, 2/23/1934, FBI file 80-69-6. 20. William H. Drane Lester, memorandum for J. Edgar Hoover, 3/30/1934, FBI file 80-69-9. 
as head of the Crime Records Division, the Black Chamber reference was forgiven in the context of the generally highly favorable image of the Division of Investigation in Wilson's series.

As time passed, contact between the FBI and the Register and Tribune in the 1930s followed the FBI's preferred template. Reporters or editors seeking access to popular stories about the FBI were expected to accept the bureau's rules of engagement. The FBI exercised tight control over its information, and when it did provide access, a journalist could expect that the agency would carefully review the resulting stories (clips of which were typically forwarded to Washington by the nearest SAC as part of their daily public relations duties). The bureau's public relations staff typically responded to stories deemed critical or inaccurate with a tendentious letter over Hoover's signature. Early exchanges between the FBI and the Register and Tribune were relatively cordial, but there were some points of contention.

In 1939 Des Moines SAC Frank Holloman forwarded a memorandum to his supervisor summarizing "crime conditions" in Des Moines. The packet of information included a list of Des Moines public officials, a listing of key staff of the Des Moines Register and Tribune, and an overview of the FBI's contacts with the newspaper, noting editorials in 1936 and 1938 that praised the bureau; editorial cartoons by a Hoover favorite, J. N. "Ding" Darling; and reviews of several news stories about the FBI written by Richard Wilson in Washington. Holloman judged relations with the Register and Tribune as friendly, with the exception of one article.

Holloman's memorandum discussed that article, a news story by Wilson that appeared on December 17, 1936, extensively. The story obliquely criticized Hoover in connection with the capture of bank robber and kidnapper Harry Burnette (Tolson had personally made the arrest in New York to boost his thin law enforcement credentials). Holloman wrote, "Although Wilson did not make personal statements in this article concerning the Director, his innuendos were such as to have the impression of a condemnation of the Director's activities in connection with that case." 21 The story insinuated irresponsible behavior

21. F. C. Holloman, summary memorandum for Mr. Hendon, "The Des Moines Register and Tribune," 12/6/1939, FBI file 94-8-137-unserialized. 
by the FBI director, a direct challenge to one element of the bureau's public relations template, thus undermining the agency's legitimacy.

Retribution was swift and, seemingly, final. As a result of that article, Wilson and all Des Moines Register and Tribune personnel were removed from the FBI mailing lists, the equivalent of being put on a blacklist. The restoration of mailing privileges in 1937 demonstrates how the bureau re-evaluated its relationships periodically. ${ }^{22}$ However, another more contentious editorial severely damaged the relationship in 1940.

In February 1940 FBI raids on the Detroit homes of activists accused of having volunteered to fight in the Abraham Lincoln Brigade in the Spanish Civil War precipitated another series of critical news stories that threatened the FBI's legitimacy. The 18 people accused had, according to the FBI, violated a federal law prohibiting recruitment of Americans to fight in foreign wars. It was not the charges, though, that alarmed the FBI's critics. The tactics of the raids disturbed critics who feared potential abuses of power by federal law enforcement. Bureau agents broke down doors at 5 a.m. and allegedly conducted warrantless searches of homes and offices of the accused. Defendants were not allowed to contact lawyers and were paraded in chains before press photographers. Editorials in the Milwaukee Journal, the New Republic, and the New York Daily News expressed outrage. The charges represented a direct threat to the bureau's carefully constructed public relations message of responsibility and utility and led to a U.S. Senate inquiry into law enforcement methods. ${ }^{23}$

Former Republican turned Independent Senator George Norris of Nebraska wrote to Attorney General Robert H. Jackson expressing his concern about the FBI's conduct. Norris repeated the charges of mistreatment that had been reported in the press. He noted that by the time of the arrests the Spanish Civil War was over, and the accused "were not criminals; there was no reason to believe that any of them would try to escape. They were not charged with an offense that had any odium at-

22. Milton A. Jones, memorandum for Cartha DeLoach, 5/11/1959, FBI file 948-137-107.

23. Theoharis et al., eds., The FBI, 114. 
tached to it; and yet they were treated as if they were wellknown to be criminals of the lowest type." 24

As later became a pattern when critical incidents occurred, Hoover responded by demonizing, without identifying, his enemies, accusing them of a coordinated smear campaign against the FBI by anti-American forces. In a series of speeches to conservative groups, Hoover drew clear lines between his critics and his supporters. In so doing, he emphasized differences between those who adhered to the FBI's version of patriotism and those who did not. His critics were "international confidence men," "conspiring Communists, their fellow travelers, mouthpieces and stooges," and made up a "fifth column," bent on destroying the nation that Hoover's restrained agents and their dispassionate, scientific law enforcement techniques were protecting. ${ }^{25}$

Hoover delivered one of those speeches to a meeting of the Daughters of the American Revolution. His characterization of his critics as communists or fellow travelers caught the attention of Register and Tribune editors. In his speech, Hoover defended his bureau and said its critics were anti-American.

I charge that accusations in dictating a purpose on the part of the Federal Bureau of Investigation to become an OGPU or Gestapo, a national police, or anything resembling such bodies, emanate directly, or indirectly from certain anti-American bodies who hope to discredit the FBI as a step in a general plan to disrupt the entire United States or from well-meaning, but misinformed persons who have fallen for the lies and utterly false information of those who would tear asunder America's machinery of law enforcement. ${ }^{26}$

On April 20, 1940, the Register responded with an editorial headlined, "Whoa, Now, Edgar, Let's Clarify!" The editors said that they were unanimously in support of the FBI's work, but suggested that Hoover was unfairly categorizing his critics.

But we hope J. Edgar isn't trying to convey the impression that anybody who at anytime criticizes something the FBI does, must therefore be "anti-American" or Communist. ... We hardly think Senator Norris, for example, who was incensed by the high-handedness

24. Senator George Norris to Attorney General Robert H. Jackson, 2/22/1940, FBI file 94-4-4514-1X.

25. Theoharis et al., eds., The FBI, 115.

26. Des Moines Register, 4/19/1940. 
of the FBI's Detroit raids, is either a Communist or even "antiAmerican." No, we don't think the FBI wants to become an "Ogpu" [sic] or "Gestapo." But we certainly don't think it needs to be immune to debate and criticism, either. Just so we understand each other, Director! ${ }^{27}$

The editorial directly undermined two elements of FBI public relations and legitimation campaigns by directly criticizing Hoover and suggesting that agents in the Detroit raids were overzealous. FBI officials responded first by trying to arrange a meeting between Register and Tribune president and publisher Mike Cowles and a prominent Des Moines citizen, Dr. Tom Denny. Denny owned the Insurance Exchange Building that housed the FBI's local office and was a close friend of the Cowles family. Denny, agent R. C. Hendon suggested, should sit down for dinner with Cowles, discuss the situation, and "try to straighten them [sic] out." 28

Hoover further suggested that Cowles be sent a letter because "they have distorted my speech \& only read part of it." 29 On April 24 Hoover wrote to Cowles, "I want to reiterate to you that very definitely the recent campaign which has been directed against the Bureau was inspired by un-American forces and through the lies and misinformation which they distributed, well-meaning and otherwise sincere persons were victimized by their falsehoods. . . . It is your duty to criticize freely when there is a need; it also is the American duty to stand by the brave, honest, efficient officers who give of their best for the communities they serve." 30 Hoover's staff did not believe that Cowles was behind the attack, but just a few weeks before, on March 14, Cowles had raised concerns about the Detroit raids with the FBI's Des Moines SAC E. R. Davis. "In this connection," Davis reported to Hoover, "MR. COWLES stated that possibly the Bureau Agents were caught off first base at Detroit, Michigan." 31

27. Des Moines Register, 4/20/1940, FBI file 94-8-137-56.

28. R. C. Hendon, memorandum for Clyde Tolson, 4/20/1940, FBI file 94-8-13756X.

29. Ibid.

30. J. Edgar Hoover to Gardner Cowles, 4/24/1940, FBI file 94-8-137-56X. (Note that related FBI documents often carry the same internal serial number.)

31. E. R. Davis to J. Edgar Hoover, 3/14/1940, FBI file 94-8-137-52. 


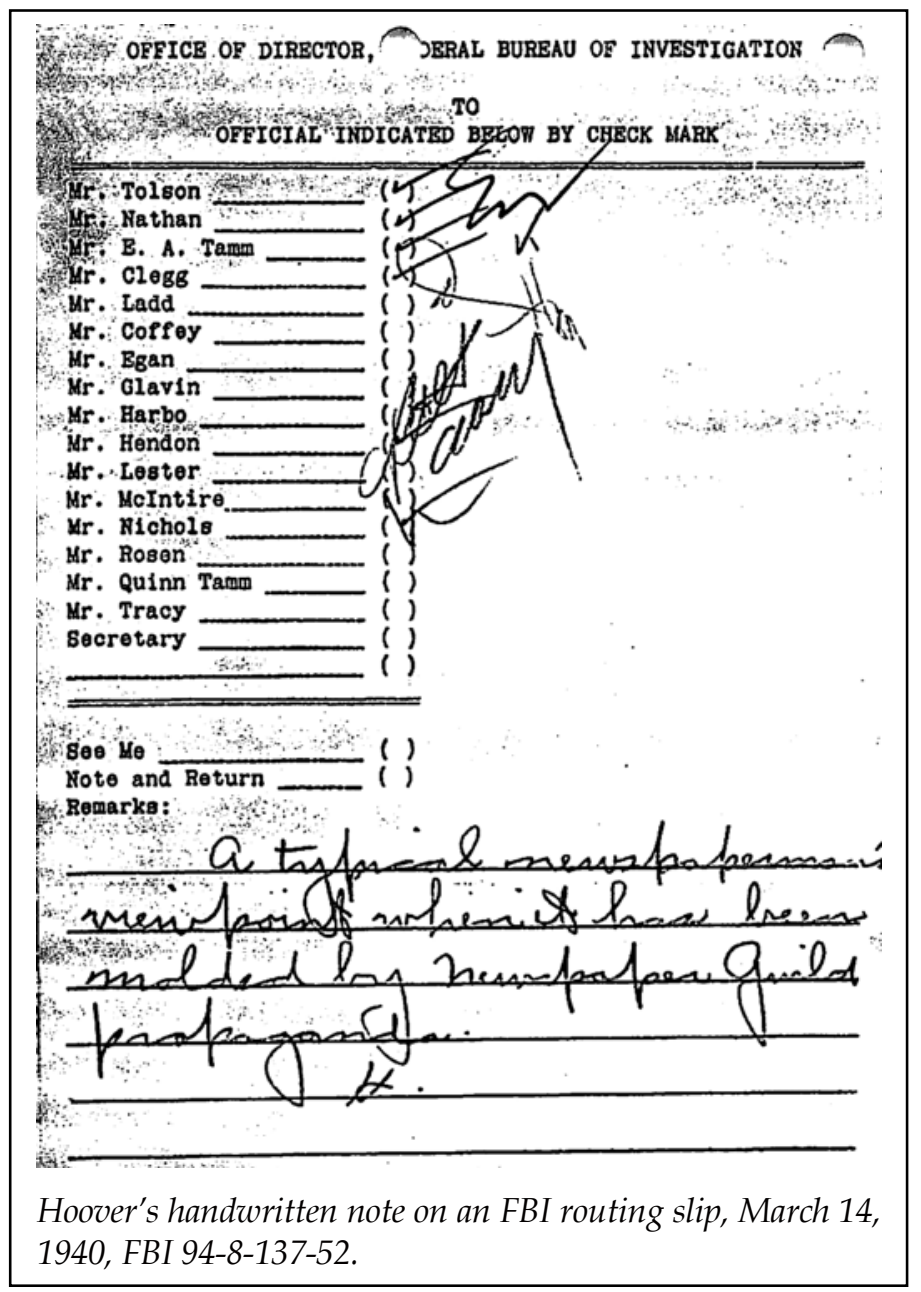

Two months later, Des Moines Register reporter Don Grant told SAC Davis that he believed the FBI had been irresponsible in the Detroit raids. According to Davis, Grant "believed some of the criticisms were well-taken. ... Thereafter, he commented on the possibility of the F.B.I. becoming a Gestapo, etc." Davis told Grant that the FBI "was doing more to guard the civil liberties of this country than any other organization," and then reported the conversation to his superiors. When Hoover read the memorandum, he dismissed it as more evidence of the untrustworthiness of the Register and Tribune: "A typical news- 


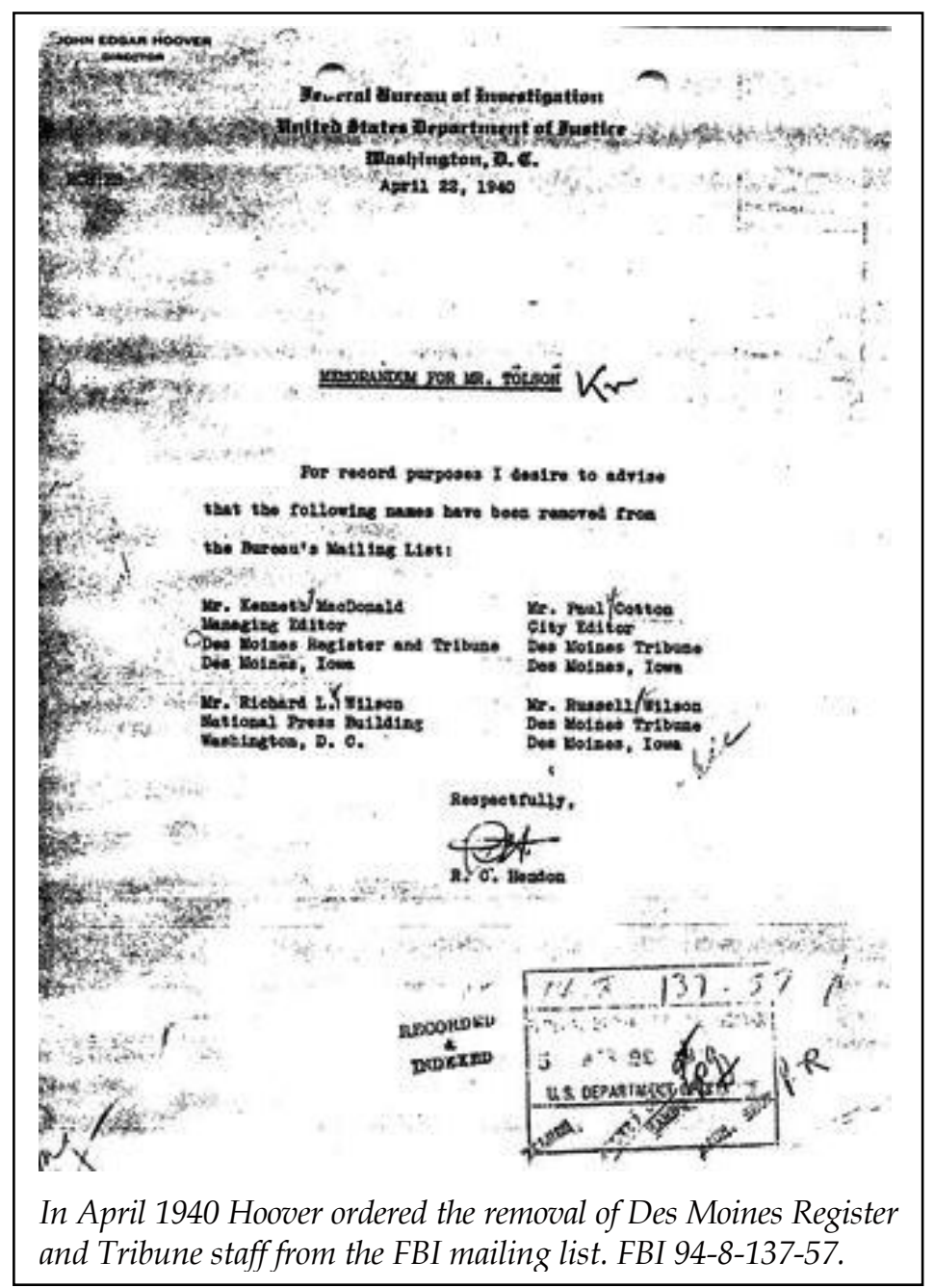

paperman's viewpoint when it has been molded by Newspaper Guild propaganda." 32

As a result of the "Whoa, Edgar" editorial, the FBI again removed all Register and Tribune staffers except Darling from its mailing list. ${ }^{33}$ Mailing list privileges were subsequently restored,

32. Ibid.

33. Robert C. Hendon, memorandum for Clyde Tolson, 4/22/1940, FBI file 948-137-57. 
but the FBI continued to assert that the criticisms were part of an organized "smear campaign" by its enemies. The bureau did not forget what it saw as an anti-American attack by "Newspaper Guild" propagandists. It was the type of black mark that remained on the Register and Tribune's FBI record, shaping the bureau's relationship with the publications for decades. In 1942, for example, Nichols requested a listing of newspapers deemed unfriendly to the FBI due to their editorial policies. The Des Moines Register and Tribune were among approximately 15 newspapers on the list with the reason listed as "derogatory editorial." 34

By October 30, 1945, the FBI was ready to begin rebuilding its relationship with the Register and Tribune. After a laudatory article about the bureau by George Coleman appeared in the Register, Hoover's public relations aides suggested that the director write to Coleman to thank him. "In view of the lapse of time since [the publication of the 'Whoa, Edgar' editorial] and insofar as it does not appear any worthwhile purpose would be accomplished in not writing to a staff member of this newspaper at this time, it was felt that a letter of appreciation might now be in good order," Nichols wrote in a note attached to a letter for Hoover to sign. ${ }^{35}$

Just six weeks later, though, the bureau noted another critical report in the Register. On December 5, 1945, the Register published a story by Nat Finney headlined "FBI Charges State Department Favors Reds." The story claimed that Hoover had leaked information to reporters about alleged communist sympathizers in the State Department. The leak, according to Finney's unnamed sources, was retaliation for the State Department clearing two spies arrested by the FBI. "G-men have been shadowing state department people for a long time," Finney wrote, "and the story planted in New York is regarded here as an open invitation to congress to ask the FBI what it has uncovered." 36

34. Memorandum for Louis B. Nichols [redacted], 3/1/1942, FBI file 94-8-45. Inexplicably, the FBI's FOIA censors redacted the names of the other newspapers. None of the exemptions provided in the FOIA account for keeping the names of newspapers private, and no exemption is cited on the document.

35. Louis B. Nichols, note on J. Edgar Hoover letter to George Coleman, 10/30/1945, FBI file 94-8-137-74.

36. Des Moines Register, 12/5/1945. 
The vengeful, secretive FBI depicted in Finney's story was again a direct challenge to public perceptions of the restrained, responsible agency the bureau carefully cultivated. Hoover was incensed and, in a rare move, circumvented the agents who usually wrote his correspondence and personally penned a letter to Editor William W. Waymack. The story was inaccurate and damaged an ongoing operation, Hoover told Waymack. "For your strictly confidential information, the premature publicizing of these cases has rendered ineffective detailed work performed over a considerable period of time," Hoover wrote. In a sentence included in his handwritten letter but edited out of the final, typewritten version sent to Waymack, Hoover claimed, disingenuously, "It has not been the practice of this Bureau to indulge in 'news leaks' or in 'planted stories.'" Waymack admitted that Finney had erred by "stating categorically what was a belief or a contention" and offered to print Hoover's response, or to send Washington correspondent Richard Wilson to interview the director. Hoover, in a letter written by Nichols, refused both options. ${ }^{37}$

Another critical editorial, published on July 19, 1955, was forwarded to Washington by the Des Moines SAC. The editorial, headlined "Using Informers," implicitly criticized the FBI and the Department of Justice for relying on paid informers to solve crimes. "Mr. Hoover is mistaken if he has gained the impression that criticism that occasionally has been directed at the use of confidential and paid informers is intended as a campaign to end the practice." Instead, the editors said, criticism of the use of informers is based on the Justice Department's tendency to insufficiently vet informers' reliability. The editorial, however, began and ended with praise for the FBI, leading off by praising the bureau's 92 percent success rate in criminal cases that year and then closing with "that is the essence of the very best kind of law enforcement." Once again, Hoover characterized a handful of critical statements as representing an organized smear campaign by anti-American forces intent on destroying the FBI. And despite its praise for the FBI, key Crime Records staff mem-

37. J. Edgar Hoover to William W. Waymack, 12/13/1945, FBI file 94-8-137-75; Waymack to Hoover, 1/24/1946, FBI file 94-8-137-78; Hoover to Waymack, 1/31/1946, FBI file 94-8-137-unserialized. 
ber Milton A. Jones evaluated the editorial as a harsh criticism. "After admitting the necessity of using 'informers,'" Jones wrote, "the editorial, by implication, accuses Mr. Hoover of being mistakenly concerned over current criticisms of the use of informants." Jones then summarized the bureau's relations with the Register and Tribune as "spotty." "There have been instances of unwarranted criticism and untruthful statements concerning the FBI appearing on its editorial pages," Jones wrote. He reminded Hoover that everyone connected with the Register and Tribune had been removed from FBI mailing lists in 1940 after the "Whoa, Edgar" editorial. ${ }^{38}$

Jones's 1955 memorandum was not the last time representatives of the FBI pointed out the critical story of 1936 and the "Whoa, Edgar" editorial as examples of the bureau's troubled relationship with the Register and Tribune. In 1958 a note on an outgoing letter addressed to Ogden G. Dwight, TV editor for the Register and Tribune, noted that the bureau's "relations with this newspaper have fluctuated in the past 20 years." A 1959 memorandum discussing a request from Richard Wilson to meet with Hoover noted the critical story he had written in 1936 and the "Whoa, Edgar" editorial. The black mark of the 1936 story and the 1940 editorial appeared again in a note appended to a 1960 letter. References to the early clashes between the FBI and the Register and Tribune continued through the 1960s, with the final reference to the "Whoa, Edgar" editorial appearing in an explanatory note attached to a letter from Director Clarence M. Kelley to Register Assistant City Editor William T. Kong in 1973, more than a year after Hoover's death. ${ }^{39}$

THE BLACK MARK of the critical 1936 and 1940 publications lingered in FBI files and disrupted the relationship between the bureau and the Register and Tribune from time to time, but it did

38. Des Moines Register and Tribune, 7/15/1955; Milton A. Jones, memorandum to Louis B. Nichols, 7/26/1955, FBI file 94-8-137-89.

39. J. Edgar Hoover to Ogden G. Dwight, 6/4/1958, FBI file 94-8-137-unserialized; Milton A. Jones, memorandum for Cartha DeLoach, 5/11/1959, FBI file 94-8-137-107; J. Edgar Hoover to Ogden G. Dwight, 12/6/1960, FBI file 94-8137-110; Clarence M. Kelly to William T. Kong, 11/23/1973, FBI file 94-8-137120. 
not stop Nichols and his staff in the Crime Records Division from building relationships with individual reporters and editors from the newspapers. The bureau refused to forget perceived sleights, but it was unwilling to completely sever its connections to reporters and editors at the only statewide newspapers in Iowa. Those individual relationships, though, depended on the reporters and editors themselves initiating contact, currying favor with the bureau, and delivering publications the FBI found worthy of its time and attention. In a few instances, Des Moines reporters and editors were willing to allow the FBI to review and edit their work prior to publication.

In 1936, for example, Vernon Pope contacted the FBI for help with a feature and photo story on kidnapping, bank robbery, and white slavery that was slated for the first issue of Look magazine, a Cowles publication, that would be inserted in 13 newspapers across the country. Pope agreed to provide copies of the five-page series to the FBI prior to publication. He sent them on November 30, 1936. Hoover's Crime Records Division reviewed the series and on December 10 sent Pope three pages of highly detailed corrections and clarifications with a note saying, "I deeply appreciate your thoughtfulness in forwarding to the Bureau the above magazine pages which are being returned to you under a separate cover." The corrections did not reach Pope in time, so the feature ran in its original form. Pope apologized to Hoover: "Unfortunately we had to close the issue before your letter was received. I am under the impression that we have made no serious errors but I am sorry we did not get your suggestions in time, as they would have improved the pages." 40

Again, in 1937, a Register reporter agreed to allow the FBI to preview and edit a series of stories. Reporter William Nelson called the FBI on September 2, 1937, requesting information about the bureau's use of science to solve crimes. No doubt pleased with the opportunity to publicize a key element of their public relations message, Crime Records Division officials forwarded a large packet of case summaries and photographs along with a letter from Hoover. "After you have prepared your

40. Vernon Pope to J. Edgar Hoover, 10/29/1936, FBI file 94-8-137-21; J. Edgar Hoover to Vernon Pope, 12/10/1936, FBI file 94-8-137-28; Vernon Pope to J. Edgar Hoover, 12/16/1936, FBI file 94-8-137-29. 
script," Hoover wrote, "I shall be very glad to have it reviewed prior to publication." After speaking with Nichols by phone, Nelson agreed. "He stated that he wanted to be perfectly honest with the Bureau," Nichols reported to Tolson, "but that the material which he prepared was not prepared in final form and was drawn over by the copy writers out in Des Moines. However he was quite sure they would follow his request that prior to publication a copy of the publication be sent to him in order that he might send it to the Bureau for review." 41

In 1953 Richard Wilson called Nichols looking for a specific document, the identity of which was redacted in the file. According to Nichols, "Wilson stated that if he could get possession of such a document and wrote a series of articles, what he would like would be to bring the articles over here and then let us edit out anything that should not go in." 42

The willingness to allow prior review of published stories about the FBI suggests how far journalists might go to gain access to the bureau's exploits, which were popular with readers. In most cases, though, reporters courting favor with the bureau simply resorted to flattery and expressions of support for the FBI's work.

In 1955 Cowles Publications reporter Fletcher Knebel was working on a story about Hoover for the Cowles newspapers, including the Des Moines Register and Tribune. When Nichols was informed that Knebel was interviewing former special agents, he notified Tolson and submitted a memorandum on the reporter, who was referred to as a "close contact" of the FBI. Nichols explained, "By the term 'close contact' ... it was meant that Knebel has been cooperative in the past, his attitude has been good regarding our work, and he has been most generous in allowing us to see his finished products prior to publication." 43

Wilson, the author of the 1936 article, continued to mine his relationship with the FBI and Hoover for stories periodically

41. J. Edgar Hoover to William Nelson, 8/31/1937, FBI file 94-8-137-32; Louis B. Nichols, memorandum for Clyde Tolson, 9/3/1937, FBI file 94-8-137-33.

42. Louis B. Nichols, memorandum for Clyde Tolson, 11/10/1953, FBI file 9433693-16.

43. Louis B. Nichols, memorandum for Clyde Tolson, 3/3/1955, FBI file 9433693-22. 
throughout his tenure as Cowles Media's Washington Bureau Chief. A former Register city editor, Wilson was 28 when Mike Cowles sent him to Washington to open a news bureau. ${ }^{44} \mathrm{~A}$ summary of the bureau's relationship with Wilson, requested by Nichols in 1950, reviewed the FBI's contacts with the reporter. According to the report, Wilson was interviewed two or three times in connection with espionage cases and was cooperative; he invited Hoover to a cocktail party in 1945; he was understanding when Nichols refused to provide information for an article on communism in 1946; and he had contacted Hoover personally in relation to a fundraiser for the Urban League. ${ }^{45}$

As was typical in FBI public relations, Wilson enjoyed periodic "personal" correspondence with Hoover, with the letters from the director authored by agents in the Correspondence Unit of the Crime Records Division. ${ }^{46}$ In a flattering 1962 letter, Wilson wrote to Hoover that he hoped the director would "not retire for a long time" and urged that "safeguards should be considered to assure that the kind of FBI you so ably run will be continued that way." Three years later, Wilson invited Hoover for cocktails after the annual Gridiron Dinner, but the director was busy. ${ }^{47}$

The relationship with Wilson was sufficiently cordial that in 1968 the bureau conducted an extensive investigation to determine whether to approach him as a PSI, Potential Security Informer. Because of their access to powerful people in their communities, security informers in the media were particularly valued in the public relations-oriented FBI. The investigation of Wilson included a check of his credit records, a review of his career's work, and interviews with other journalists who had become security informants. Hoover ultimately determined that

44. Friedricks, Covering Iowa, 88.

45. Milton A. Jones, memorandum for Louis B. Nichols, 5/11/1950, FBI file 6292208-1.

46. Hoover's use of personal correspondence, ghostwritten by his correspondence staff, to develop faux personal relationships with reporters and editors was a common tactic of FBI public relations. See Cecil, "Friends of the Bureau," 267-84.

47. Richard L. Wilson to J. Edgar Hoover, 9/6/1962, FBI file 62-92208-2; Richard L. Wilson to J. Edgar Hoover, 3/17/1965, FBI file 62-92208-3. 
Wilson "would not appear to be the type of individual who would be amenable to direction in a controlled operation." 48

During Wilson's tenure as Cowles Media's Washington Bureau Chief, there were lengthy gaps between FBI contacts. For example, the FBI did not provide any information to Wilson for ten years starting in 1949. In 1959 the silence was broken when Wilson wrote to request a statement from Hoover about crime in the Midwest and comments on his thirty-fifth anniversary as FBI director. In his request, Wilson reminded then Crime Records Division head Cartha DeLoach of his first collaboration with the bureau, his 1934 kidnapping series. DeLoach's top aide recommended that the bureau cooperate with Wilson despite his authorship of the critical 1936 story. "It would appear that he is sincere in his desire to write a favorable story re the Director and the Bureau," Jones told DeLoach. ${ }^{49}$

MORE THAN any other Register and Tribune or Cowles Media reporter, Clark Mollenhoff maintained a close contact with the FBI. Mollenhoff was hired to join the Washington Bureau of Cowles Publications in 1950 and, except for a brief stint as an adviser to the Nixon administration, covered the nation's capital until 1978. In 1958 he won a Pulitzer Prize for his reporting on corrupt labor practices. 50

Like the bureau's relationship with the Register and Tribune generally, its relationship with Mollenhoff was a roller coaster ride, with periods of cooperation, starting with Nichols's evaluation of him in 1951 as looking "exceedingly good," punctuated by rejection and controversy. In 1953 Hoover contacted the Minneapolis SAC, noting that Mollenhoff, who wrote for Cowles newspapers in Minneapolis as well as Des Moines, would likely visit the Twin Cities. "Clark Mollenhoff is a responsible reporter and has been friendly and favorably disposed toward the Bureau

48. SAC Washington, memorandum for J. Edgar Hoover, 10/11/1968, FBI file 105-186424-unserialized, p. 9; J. Edgar Hoover, memorandum for SAC Washington, 11/1/1968, FBI file 105-186424-unserialized.

49. Milton A. Jones, memorandum for Cartha DeLoach, 5/11/1959, FBI file 948-137-107.

50. Robert D. McFadden, “Clark R. Mollenhoff, Pulitzer Winner, Dies at 69," New York Times, 3/4/1991; Friedricks, Covering Iowa, 122. 
for several years," Hoover wrote. "He should be courteously received, but no confidential information should be made available to him." 51

Mollenhoff first touched off controversy within the FBI in 1958, when he contacted the bureau to ask about an alleged change in the procedures for investigating prospective presidential appointees. Mollenhoff said he had spoken with several people at the White House who claimed that an extensive review of candidates' finances had been added to the investigative process. Hoover refused to comment, and the FBI contacted President Eisenhower's press secretary, James Hagerty, to find out who might have spoken to Mollenhoff. A change was being considered by the White House but had not been implemented, Hagerty said, claiming that no one had spoken to Mollenhoff. Hoover dismissed the incident as "just another instance of another 'eager beaver' of the press trying to hook us with a confirmation." 52

In 1961 Mollenhoff requested a meeting with Hoover to discuss law enforcement issues. Hoover's staff argued against the meeting, noting the director's "eager beaver" comment and highlighting Mollenhoff's advocacy of openness in government, not a popular position within the secretive FBI. The bureau had taken notice two years earlier when Mollenhoff obliquely criticized the FBI during a speech on the campus of Colby College in Maine that emphasized the people's right to know and journalists' obligation to press the government for information. "Columnists Drew Pearson and Joseph Alsop report that when they were critical of government policies and personalities, they found themselves subjected to the investigations of agents of the FBI and other government bureaus. They contended that no breach of security was involved but that they were subjected to probes to dry up their sources of information." 53

The Colby College speech, along with a report that President Eisenhower had told Mollenhoff to "sit down" during a

51. J. Edgar Hoover, memorandum to SAC, Minneapolis, 1/27/1953, FBI file 94-33693-10X.

52. Hoover note on R. R. Roach, memorandum to Alan H. Belmont, 5/23/1958, FBI file 94-33693-27

53. Mollenhoff's speech was reprinted in the Portland (Maine) Evening Express, 12/8/1959; FBI file 94-7-137-101. 
news conference and the reporter's acquaintance with Attorney General Robert Kennedy, were the reasons cited in a memorandum recommending that Hoover not meet with the reporter. ${ }^{54}$ Nonetheless, Hoover agreed to meet Mollenhoff, and the two sat down in the director's office on September 29, 1961. During the meeting, Mollenhoff requested information on Soviet espionage, on a 1960 speech by United Nations Ambassador Henry Cabot Lodge, and on Dipa Nusantara Aidit, an aide to President Sukarno of Indonesia. At the end of the meeting, according to FBI notes, Mollenhoff expressed his appreciation and said he was "going to keep in touch with the Director because he found his views to be stimulating and reassuring." 55

After the meeting, Mollenhoff told a Hoover aide that the director's views paralleled his own. Following the meeting, Mollenhoff was added to the FBI's Special Correspondents List to receive additional bureau mailings. ${ }^{56}$ The meeting began a brief period of particularly cordial relations between Hoover and Mollenhoff. A few months later, Hoover's letter writers wrote on his behalf to congratulate Mollenhoff on winning a John Peter Zenger Award for his efforts on behalf of press freedom. Mollenhoff replied, thanking Hoover for sending an autographed photograph. "I admire your restraint as much as your wisdom in your comments on the problems of law enforcement," Mollenhoff wrote. "I doubt if I would be as restrained as you are if I had faced the problems for such a long time." 57

In 1968 Mollenhoff again requested a meeting with Hoover. This time his request was rejected in a memorandum with extensive redactions. ${ }^{58}$ The 1968 rejection was, it appears, based

54. Milton A. Jones, memorandum for Louis B. Nichols, 9/18/1961, FBI file 9433693-34.

55. Milton A. Jones, memorandum for Cartha DeLoach, 10/2/1961, FBI file 9433693-36.

56. Cartha DeLoach, memorandum for John Mohr, 9/29/1961, FBI file 9433693-42. A 1954 review of the Special Correspondents List found that the list included 300 people, including 75 newsmen considered "most friendly." Memorandum for Louis B. Nichols [redacted], 3/26/1954, FBI file 62-21531-1093.

57. J. Edgar Hoover to Clark Mollenhoff, 12/4/1961, FBI file 94-33693-41; Clark Mollenhoff to J. Edgar Hoover, 1/16/1962, FBI file 94-33693-43.

58. Milton A. Jones, memorandum for Thomas Bishop, 1/3/1968, FBI file 9433693-45. 
on new information about Mollenhoff's close relationship with Robert F. Kennedy, a Hoover nemesis. 59 Then in 1971 Mollenhoff requested an interview with Tolson, who had once lived in Iowa, for a feature story. Tolson refused. Hoover agreed with the decision. When a staff member called the director's office to report that Mollenhoff had been so advised, Hoover scrawled, on the phone message, "No one in the Bureau should see this 'rat.' "60

The FBI had been aware of Mollenhoff's acquaintance with Kennedy before earlier meetings. So what caused Hoover to permanently sever ties with the "rat" Mollenhoff in 1971? The likely cause was a series of 1970 special television news reports on Hoover by CBS News reporter John Hart. For his five-part series, Hart interviewed former attorneys general, members of Congress, and Clark Mollenhoff. ${ }^{61}$ Hoover refused to participate. The critical series suggested that Hoover had remained in office too long. A few weeks after the story aired, Mollenhoff, then in the midst of a brief stint on President Richard Nixon's White House staff, requested information from Hoover. "No," Hoover wrote on the request. "Let him get what information he wants from [Assistant to the President for Domestic Affairs John] Erlichman. Mollenhoff participated in a recent 'hatchet' job done by CBS." 62

BEGINNING IN 1934, the FBI's public relations staff carefully monitored and evaluated its relationships with the Des Moines Register and Tribune and its affiliated publications and bureaus. The SAC in Des Moines scanned the local newspapers daily and forwarded pertinent clippings, along with explanatory memoranda, to the FBI's Washington headquarters. There, staffers in

59. Hoover mentioned Mollenhoff's relationship with Robert Kennedy in a 1971 note on a memorandum, Milton A. Jones to Thomas Bishop, 3/3/1971, FBI file 161-1848-88. At the bottom of the memorandum discussing another rejection of a Mollenhoff requests, Hoover wrote, "He always was close to Bobby Kennedy."

60. Thomas E. Bishop, memorandum for John Mohr, 4/9/1971, FBI file 94-8137-118; Phone message for J. Edgar Hoover, 4/9/1971, FBI file 94-8-137-117.

61. Thomas Bishop, memorandum for Cartha DeLoach, 1/8/1970, FBI file 1611848-87.

62. Memorandum for William C. Sullivan [redacted], 1/22/1970, FBI file 1611848-88. 
the Crime Records Division evaluated the material and maintained an ongoing record of the ups and downs of the bureau's relationships with reporters, editors, and publications. Agendasetting national publications and prominent national reporters received particular attention, but local and regional publications like the Des Moines Register and Tribune were also closely monitored. Critical editorials were noted and, in some cases, merited a response. Reporters' inquiries were fielded and considered. The rubric for considering some publications and reporters friends and others as foes was based on the FBI's public relations template emphasizing restraint, science, and a positive image of Hoover.

A critical story that undermined the FBI public relations template might result in a temporary removal from the bureau's mailing lists as happened twice to Des Moines Register and Tribune staff. A friendly story conforming to the FBI's public relations template might result in being considered a friend even when one's publication was critical, as with Hoover's continued relationship with editorial cartoonist Jay N. "Ding" Darling. Stories or editorials that undercut the bureau's public relations messages by alluding to concerns about federalized police powers or, even worse, questioning Hoover's proclamations, could remain on a publication's FBI record for decades.

The FBI's up-and-down relationship with the Des Moines Register and Tribune and with key staffers like Richard Wilson and Clark Mollenhoff typifies its relationships with many other regional publications during the Hoover era. Some journalists and publications became adjuncts to the FBI, uncritically amplifying Hoover's xenophobic and paranoid worldview or attacking the director's critics when asked. ${ }^{63}$ Others became outspoken critics of the FBI, risking Hoover's wrath and the wrath of his media allies. ${ }^{64}$ Register and Tribune staff, for the most part, kept some editorial distance from the bureau and occasionally gently criticized Hoover and the FBI, but at times some of them were willing to flatter Hoover or fit their reporting to FBI public relations rubrics in order to secure access to information.

63. See, for example, Cecil, "Friends of the Bureau."

63. See, for example, Matthew Cecil, " ‘Press Every Angle’: FBI Public Relations and the Smear Campaign of 1958," American Journalism 19 (2002), 39-58. 